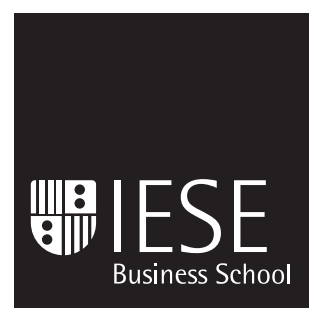

Anselmo Rubiralta Center

Working Paper

WP no 623

for Globalization and Strategy

March, 2006

University of Navarra

\title{
CORPORATE STRATEGY IN TURBULENT ENVIRONMENTS: KEY ROLES OF THE CORPORATE LEVEL
}

\author{
Adrián A. Caldart \\ Joan Enric Ricart
}

IESE Business School - Universidad de Navarra

Avda. Pearson, 21 - 08034 Barcelona, España. Tel.: (+34) 932534200 Fax: (+34) 932534343

Camino del Cerro del Águila, 3 (Ctra. de Castilla, km 5,180) - 28023 Madrid, España. Tel.: (+34) 913570809 Fax: (+34) 913572913

Copyright ${ }^{\odot} 2006$ IESE Business School. 
The Anselmo Rubiralta Center for Globalization and Strategy aims to be an international benchmark for companies, universities, business schools and governments. It promotes the exchange of ideas in the area of globalization and international strategy.

The Center's main objectives are to:

- Develop a conceptual structure that will help companies to understand and manage the impact of globalization and develop strategies of internationalization;

- Generate and disseminate new knowledge in this field;

- Develop new, high-quality teaching materials.

www.iese.edu/globalcenter 


\title{
CORPORATE STRATEGY IN TURBULENT ENVIRONMENTS: KEY ROLES OF THE CORPORATE LEVEL
}

\author{
Adrián A. Caldart* \\ Joan Enric Ricart**
}

\begin{abstract}
This paper analyzes the evolution during the period 1986-2002 of the corporate strategy of Lujan, a highly successful car components manufacturer headquartered in Spain, as a way to explore how the corporate level influences the successful evolution of a company exposed to a "turbulent" environment over a long period. We find that the corporate level plays three key roles. First, it drives a firm's evolution by developing a cognitive representation of the firm's competitive landscape. Second, it paces the company's evolution by alternately shifting the balance of organizational initiatives between static efficiency-based "local search" strategies, chosen in times of stability or economic slowdown, and dynamic efficiency-based "long jump" strategies, adopted during periods of major environmental turbulence. Long-jump corporate strategies, carried out through limited downside strategic initiatives such as real options and strategic alliances ("off-line long-jumps"), are particularly frequent in these circumstances. The third role consists of developing an organizational architecture that frames the self-organized coordination of the different business divisions. The Lujan story clearly illustrates the important role of corporate strategy in a firm that must undergo radical transitions as a result of major environmental changes.
\end{abstract}

* Warwick Business School, University of Warwick

** Professor, General Management, IESE

Keywords: corporate strategy, turbulent environments, complexity theory, car components. 


\section{CORPORATE STRATEGY IN TURBULENT ENVIRONMENTS: KEY ROLES OF THE CORPORATE LEVEL}

\section{Introduction}

The issue of whether and how the corporate level contributes to competitive advantage has aroused fierce controversy during the last two decades. Work aimed at identifying the sources of corporate performance by isolating company, industry and corporate effects (Schmalensee, 1985; Rumelt, 1991; Mc Gahan and Porter, 1997) concluded that corporate effects appeared to be negligible. More recently, this long-standing "truth" of strategic management has been challenged by studies that find material corporate effects (Brush and Bromiley, 1997; Chang and Singh, 2000; Bowman and Helfat, 2001). However, studies within this tradition appear to be strongly affected by difficult-to-fix sampling biases and methodological flaws (Brush and Bromiley, 1997; Chang and Singh, 2000; Bowman and Helfat, 2001; Hawawini et al., 2003). The creation of corporate advantage may be a phenomenon of a subtlety that cannot be captured by cross-sectional database statistical studies (Bowman and Helfat, 2001), making new methodological approaches welcome. Bowman (1995) suggested that a better understanding of the design issues in corporate strategy would open a possible future for the field. A step in this direction is found in recent work rooted in the "sciences of complexity" which asserts the superiority of management systems that foster the development of self-organizing processes, as

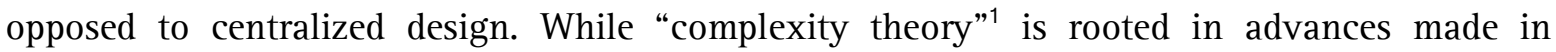
natural sciences, prominently in biology and physics, there is a growing literature by management scholars who propose insights derived from those advances (Levinthal, 1997; Mc Kelvey, 1997, 1999; Brown and Eisenhardt, 1998; Conner, 1998; Anderson, 1999; Boisot and Child, 1999; Clippinger, 1999; Gavetti and Levinthal, 2000; Stacey et al., 2000).

From an empirical viewpoint, we distinguish two streams of research that approach organizations as complex systems. Both conserve traditional organizational design theories' focus on interdependencies but put the stress on the ability to manipulate these interdependencies, and on the performance implications of such manipulation (Brown and

Sponsors: We gratefully acknowledge support for this research from IESE Business School's Anselmo Rubiralta Center for Globalization and Strategy.

\footnotetext{
${ }^{1}$ Studies that rely on the message of the complexity sciences (Bar-Yam, 1997) do not constitute a unifying theory, as authors diverge in the way key properties of complex systems observed in natural sciences are understood and researched in organizational contexts.
} 
Eisenhardt, 1998; Gavetti and Levinthal, 2000). The first kind of studies is characterized by systematic analysis, based on the use of agent-based simulations. The second thread is based on the study of cases, aimed at observing properties of complex systems in organizational contexts.

Agent-based modeling. NK simulations. The simulations thread was strongly based on a modeling strategy "imported" and adapted from biology: Kauffman's NK model (Kauffman, 1993). This model was originally developed in the field of biology as a way to describe the self-organizing properties of genes and the impact of those properties on the genes' "fitness". It was adopted as a modeling strategy in organization studies with the purpose of describing how the complexity of an organizational design and the kind of strategic behavior followed by a company affect its performance or "fitness".

Initial contributions within this perspective (Levinthal, 1997; McKelvey, 1999; Gavetti and Levinthal, 2000; Rivkin, 2000) constituted a very valuable effort toward the introduction of systematic analysis in the discussion of organizations as complex systems. Yet, doubts arose with respect to the possibility of studying human organizations using tools conceived originally for the study of living organisms. Issues central in organizational life, such as rational choice, near decomposable structures, risk aversion, strategic discipline, or long-term vs. short-term performance, are completely neglected in these models. Later efforts successfully addressed some of these shortcomings, incorporating features such as Simon's (Simon, 1996) idea of near decomposability (Gavetti, 1999); strategic discipline (Gavetti et al., 2003; Siggelkow and Levinthal, 2003; Caldart and Ricart, 2004); the impact of analogy on managers' cognition (Gavetti et al., 2003); and changes in the environment (Siggelkow and Rivkin, 2003).

Case-study research. Case studies rooted in complexity theory have tended to "export" properties observed in complex systems in nature to the organizational world, and put the emphasis on optimizing interdivisional collaboration in multidivisional firms exposed to turbulent environments. Turbulent environments are those characterized by high levels of dynamism, complexity and uncertainty (Crossan, Nanjad and Vera, 2001). The idea of dynamics at the "edge of chaos" (Brown and Eisenhardt, 1998; Marion, 1999) gained particular currency. Eisenhardt and Brown (1998) point out the important role of self-organizing as a process that places the company "at the edge of chaos." According to these authors, the "edge of chaos" is reached through a structural design that allows a balance to be struck between the paradoxical needs of organizations: the need for order and stability, and the need for innovation and creativity. Going too far in the search for innovation and creativity results in a rule-breaking culture, loose structures and processes that obscure responsibilities, and excessive but ineffective communication, leading to the "chaos trap" (Brown and Eisenhardt, 1998) or "error catastrophe." Conversely, going too far in the search for tight structures, schedules and processes results in a loss of flexibility, poor innovation, and a predictable strategy, leading to the "bureaucracy trap" (Brown and Eisenhardt, 1998) or a "complexity catastrophe." At the edge of chaos, firms have activities that are loosely constructed but with critical structure points, a culture of frequent change in a context of strict rules, and channels for real-time, fact-based communication within and across groups.

Another influential idea that emerged from this literature, especially in the sphere of multidivisional firms, was that of "simple rules" (Pascale, 1999; Eisenhardt and Sull, 2001). Given the superiority of self-organizing processes, as opposed to tight control, as a way to release the organization's creative forces and its sensitivity to design influences, the corporate center is left with the role of designing "simple rules" (Eisenhardt and Sull, 2001), i.e., objectives or policies that frame self-organizing at the business level. Grant (2003) reinforces 
this idea, reporting that strategic planning became less concerned with detailed action programs, commitments to particular projects, and resource deployments, and instead placed greater emphasis upon more broadly defined goals. Corporate executives are the candidates to perform this role, as they are more likely than others to have a broad architectural knowledge of the firm (Galunic and Eisenhardt, 2001). Similarly, Stacey (1993) proposes that corporate management must create the context in which collaboration can happen by bringing managers together to talk and perhaps find collaborative opportunities. In their recent multiple case study, Chakravarthy et al. (2001) also suggest that the transfer of knowledge related to the company's core competencies appears to be more effective when business units relate to each other without direct corporate intervention. Finally, Goold and Campbell (2002) propose that multibusiness companies be seen as "structured networks" in which corporate intervention is desirable only as a means to remedy the "difficult links" or coordination problems that the network cannot solve effectively through self-organizing. This literature highlights the need for a "new worldview" based on an understanding of firms as complex adaptive systems. More importantly, it proposes organizational arrangements that "fit" with the nature of complex systems and make it possible to overcome difficulties resulting from an understanding of the firm based on mechanistic paradigms. Previous studies concerning multidivisional firms (Goold and Campbell, 1987; Hill and Hoskisson, 1987; Prahalad and Hamel, 1990; Markides and Williamson, 1996) signaled the corporate center as the unit in charge of actively searching out and developing inter-unit synergies. However, these kinds of "synergy creation" efforts based on centralized designs showed poor results in practice (Goold and Campbell, 1998).

This paper constitutes an effort to build on this literature, focused on how value is created in multidivisional firms, by exploring how the corporate level influences the long-term, successful evolution of a multidivisional firm exposed to a highly turbulent environment for an extended period. For this purpose, we draw on the theoretical tradition of behavioral evolutionism (March and Simon, 1958; Cyert and March, 1963; Nelson and Winter, 1982), recently enriched by the abovementioned literature rooted in the complexity sciences (Gavetti and Levinthal, 2000; Levinthal, 1997; Levinthal and Warglien, 1999; McKelvey, 1997, 1999). To explore this issue, we carried out an in-depth historical case study of Lujan, a car component manufacturing firm headquartered in Spain that underwent radical transitions as a result of being exposed to a highly turbulent competitive landscape.

The central element of this story concerns Lujan's corporate initiatives aimed at dealing with the rapid changes that affected its industrial sector, the car component industry, during the 1980s and 1990s. Many of this industry's central business practices changed in the wake of the transformation in the automotive industry. During this period, Lujan undertook a spectacular process of international expansion, illustrated by an annual increase in sales averaging 22.3\% from 1985 through 2000 (Figure 1). The company established a presence in 18 countries in all the key geographical "centers of gravity" of the car industry worldwide and increased its number of employees from 703 in 1985 to 6,121 in 2000. Remarkably, the company's majority shareholding remained in the hands of the same two families that founded it fifty years earlier. 


\section{Figure 1}

Lujan. Evolution of sales, 1985-2001

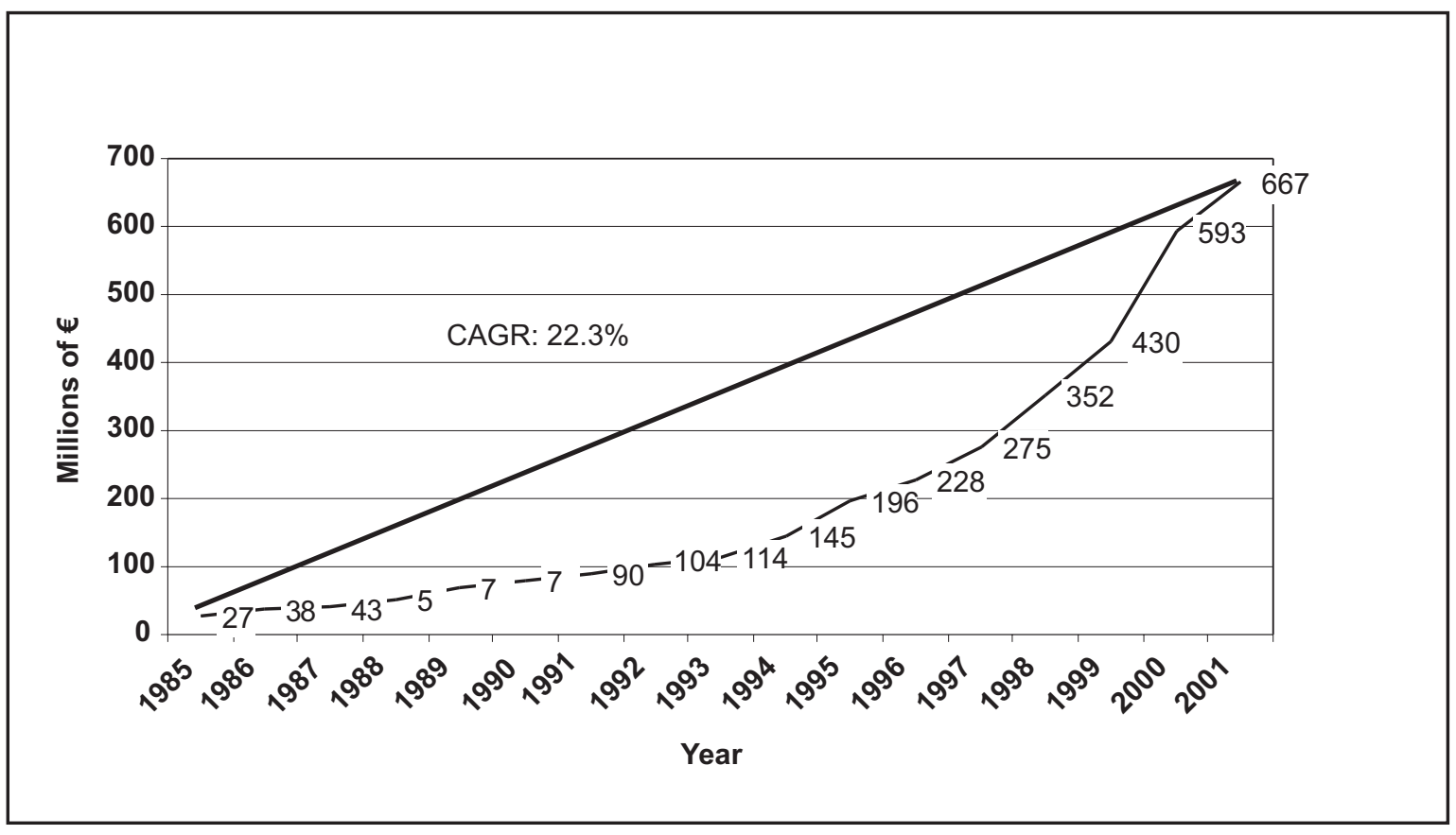

We framed data collection in a recently developed framework, the Corporate Strategy Triangle (Caldart and Ricart, 2004). This framework, discussed below, conceives that corporate strategy results from three key roles of the corporate level: the development of a corporate cognitive representation of the firm's fitness landscape; the development of corporate strategic initiatives; and the development of the firm's architectural design. We found that the contribution of corporate strategy to the firm's successful transitions was crucial in all three of these roles. Major changes in the evolution of the car components industry triggered significant alterations in corporate management's understanding of the firm's competitive landscape. These new representations triggered consistent corporate strategic initiatives affecting every major division of the firm, and also architectural re-designs aimed at addressing turbulence by fostering and easing the emergence of self-organized coordination initiatives at the divisional level.

\section{The Corporate Strategy Triangle}

The Corporate Strategy Triangle (Caldart and Ricart, 2004) is a dynamic framework for corporate strategy, based on three interlinked sets of processes (Figure 2) ${ }^{2}$. Although the processes influence each other, for descriptive purposes we will describe each one separately.

\footnotetext{
${ }^{2}$ For a more detailed discussion, see Caldart and Ricart (2004).
} 


\section{Figure 2}

The Corporate Strategy Triangle

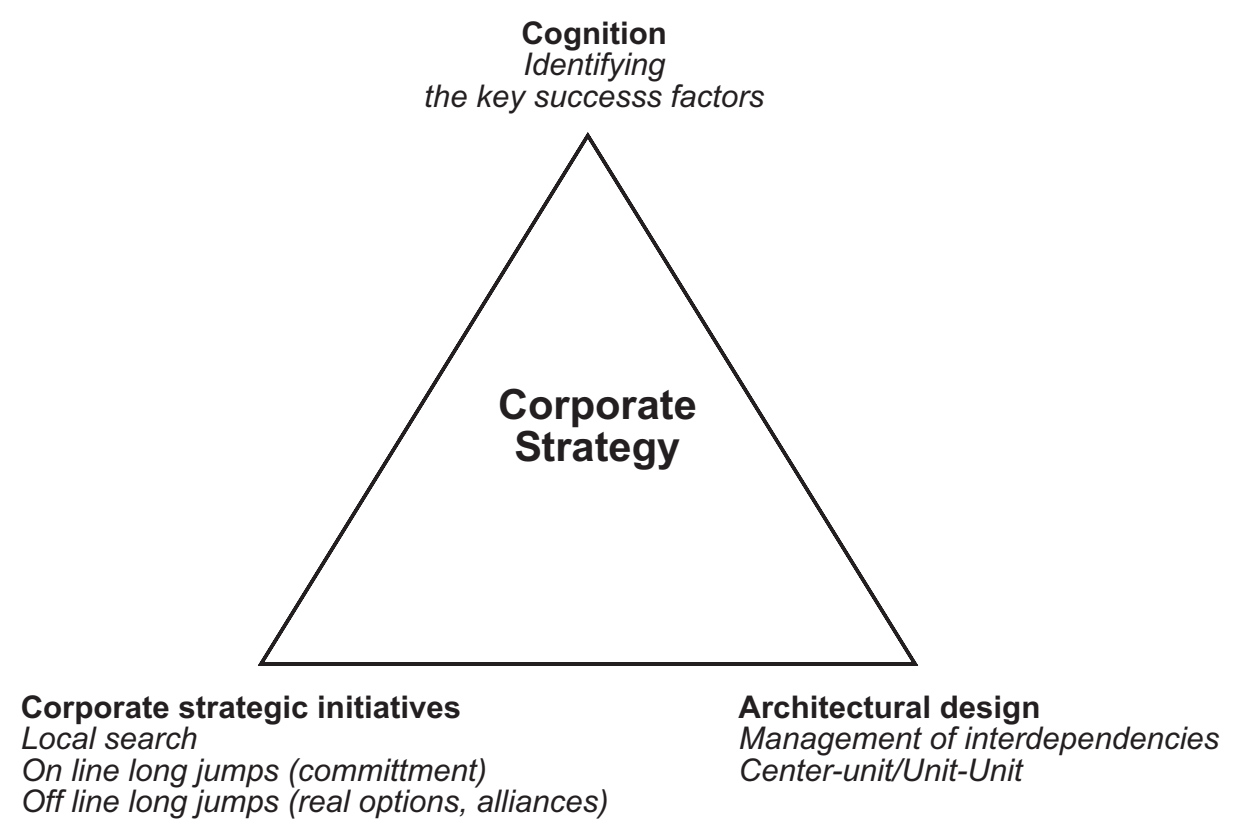

Corporate management develops a representation of the firm's fitness landscape that drives the firm's evolution. Corporate strategic initiatives are developed in accordance with that representation. Through these initiatives, the corporate level paces the firm's evolution. Finally, the corporate level designs the architecture of the firm, framing the evolution of the portfolio of businesses.

DRIVING. Developing a cognitive representation of the firm's business landscape. The corporate level develops a cognitive representation of the business landscape and uses it to define the corporate value creation model, which specifies the key success factors of the firm as a whole. Cognitive representations have been shown to be a critical determinant of managerial choice and action (Fiol and Huff, 1992; Walsh, 1995). Cognition is a forward-looking form of intelligence that is premised on an actor's belief about the linkage between the choice of actions and the subsequent impact of those actions on outcomes. Such beliefs derive from the actor's mental model of the world, or "dominant logics" (Prahalad and Bettis, 1986).

PACING. Developing corporate strategic initiatives. Based on the cognitive representation, organizations position themselves in their landscapes using different kinds of evolutionary strategies, such as incremental search, long jumps, or recombinations of resources and business opportunities. Search is local when the company aims at innovating within its current corporate model. It takes place when the set of business attributes is varied only incrementally.

In contrast to local search, long jumps involve adopting a new corporate model. This strategy is characterized by high exploration but limited exploitation, and emphasizes sample variation in the search for dynamic efficiency. The impact of this strategy varies dramatically depending on whether the evaluation mechanism is one of on-line experimentation or off-line cognition (Gavetti and Levinthal, 2000). If the evaluation of alternatives is off-line, variation in the 
sample is generally an attractive property. If low outcome draws can be discarded at low cost, the greater variance in the sample, holding the mean constant, increases the expected value of the draws that are adopted, encouraging long jumps.

A third possibility consists of recombining elements of existing partial solutions (Levinthal and Warglien, 1999; Eisenhardt and Bingham, 2003) by manipulating the interdependencies between the firm's different activities. Entrepreneurs do not randomly sample the space of alternatives, but find new, unforeseen combinations of known but previously distant elements. Galunic and Eisenhardt (2001) propose "chartering," a competitive process between units enabling recombination, or "patching" (Eisenhardt \& Brown, 1999), of product-market domains between business units in response to market changes. In this way, the company obtains intertemporal economies of scope (Helfat and Eisenhardt, 2001), arising from the replacement of old businesses that used a resource by a new business that uses the same resource, in response to changing market conditions.

If driving represents the corporate view of the landscape, pacing involves defining the key search strategy to put the corporate value creation model into action. Together they identify the way the corporate level adds value to the business portfolio. The architectural design closes the model by defining the key organizational elements to implement the value creation model.

FRAMING. Developing the Architectural Design of the Firm. Designs with low interdependence keep the level of interactions low. However, flexibility comes at the expense of poor internal diversity (or complexity). In contrast, higher interdependence promotes organizational learning, as diversity of behavior rises with interdependencies, but reduces the effectiveness of organization-level change. Tightly coupled systems have great difficulty in adapting even to modest change. The more turbulent the environment, the more interdependent the architectural design, as the firm tries to increase internal knowledge and activity sharing. This assumption is consistent with Ashby's law of requisite variety ${ }^{3}$ and Lawrence and Lorsch's (1967) Integration and Differentiation framework. In other words, in turbulent environments the organization cannot allow divisions, especially those that are related because they have common customers or technologies, the "luxury" of running totally autonomously, as very valuable knowledge and cost-sharing opportunities would be sacrificed, leading to an "error catastrophe." However increasing interdependencies expose the firm to the risk of a "complexity catastrophe."

As seen, the organizational architecture fits the cognition and search strategy to implement the underlying corporate value creation model. In this architecture it is crucial to define the level of organizational design vs. self-organization that frames corporate strategy.

\section{Methods and Data}

This research is based on an in-depth, historical, inductive case study of the evolution of the corporate strategy of Lujan over the 16-year period from 1986 to 2002. The case provides an insight into how corporate strategy leads the evolution of companies facing profound environmental changes. We chose the case study format because of the lack of a comprehensive framework for understanding the evolution of corporate strategy in turbulent environments

\footnotetext{
3 "The real key to regulation is to be able to match the variety of exogenous disturbances to the system" (Scott, 1992 on Ashby's law).
} 
over an extended period. We judge that our longitudinal design, unlike cross-sectional cases and database studies, enables us to capture the richness and understand the dynamics of the corporate strategy process.

Data collection. During our research project we had one sponsor, the CE0, while the Corporate Controller acted as a liason executive for the project.

The data collection process was framed by the Corporate Strategy Triangle. The study involved 14 semi-structured interviews (see Table 1) with the Chairman, the CEO, several corporate managers, most of whom were also members of the Board of Directors, an external board member, and the heads of the company's three international divisions. Interviews took typically an hour and a half, with the shortest taking forty minutes and the longest lasting two hours. The interviews covered the following topics:

- Major environmental changes faced by the firm during the period studied.

- Evolution of the "dominant logic" at the corporate level.

- Main corporate strategic initiatives.

- Evolution of the architectural design of the firm, emphasizing especially the evolution of corporate-division relationships and interdivisional relationships.

- Evolution of the firm's governance structure and how it impacted on the dominant logic at the corporate level, the kind of corporate strategic initiatives adopted, and the architectural design of the firm.

- Performance of the firm.

\section{Table 1}

Interviews at Lujan

\begin{tabular}{|l|c|}
\hline \multicolumn{1}{|c|}{ Responsibilities } & No. of interviews \\
\hline Chairman of the Board & 1 \\
CEO and Member of the Board of Directors & 3 \\
Executive Vice-President and Member of the Board of Directors & 1 \\
CFO and Member of the Board of Directors & 1 \\
Corporate Human Resources Director & 1 \\
Corporate Logistics Director & 1 \\
External Member of the Board of Directors & 1 \\
Corporate Controller & 2 \\
Divisional Director Rear View Systems & 1 \\
Divisional Director Cables and Command Systems & 1 \\
Divisional Director Sunvisors and Pumping Systems & 1 \\
\hline
\end{tabular}

Notes were taken during the interviews and full reports were written up immediately after each interview. 
In addition to interviews, we obtained documentary information from the company, including strategic plans, annual reports, institutional brochures and promotional films. Finally, we gathered public information from the company's website, the Spanish business press, business databases, publications specialized in the car and component industries, and a teaching case study on the company. The CEO and the corporate controller and his staff provided additional information by e-mail or telephone when further clarification was required. Finally, after the study was finished, major ideas derived from the case were discussed with the CEO, who provided comments.

Given the characteristics of our research interest, we chose a holistic approach (Yin, 1989), taking the company as a whole as the unit of analysis.

For this purpose, first, we briefly review Lujan's history from its creation through 1986 . Second, we account for the evolution in the company's corporate strategy during the period covered by the fieldwork (1986-2002), explaining how the corporate level reframed the company's environment and identifying the key strategic and organizational initiatives it led.

\section{Corporate Evolution at Lujan}

\section{Origins of Lujan 1949-1985}

After the end of World War II, Spain suffered an international economic embargo against the Franco regime. Because the country had no automobile industry of its own, isolation led to a severe shortage of spare parts for cars. This created an opportunity for local companies to enter this business by substituting imports. In this context, in 1949 Mr. Joan Roig and his brother-inlaw, Pere Feliú, founded a small firm, Lujan, with the purpose of supplying brake, clutch and speedometer cables for used cars. In the '50s, the Spanish state created two companies to produce cars and trucks, thus boosting the national demand for car components. Lujan seized this opportunity to expand its business by becoming a supplier for new automobiles and trucks. As it was in close contact with its customers, Lujan noticed the car manufacturers' additional needs and expanded its product line beyond the cable business. In this way, Mr. Roig and Mr. Feliu soon had a group of companies under their control, producing windscreen wipers, rearview mirrors, sun-visors and window handles.

The organization was strongly centralized, with CEO Mr. Roig making all the strategic and marketing decisions concerning the different businesses, with only operational management being decentralized. However, as the company grew, Mr. Roig realized that his holding responsibility for most business policy decisions was creating increasingly serious bottlenecks at the top of the company. Consequently, in 1976 Lujan became a holding company, acting as the corporate center of a multidivisional group, to which it provided commercial, financial, administrative, legal and economic services. Roig delegated all business decisions to the managers of the different companies, who from then on operated with a high degree of autonomy.

In 1986, Lujan was the leader of the Spanish cable, windscreen wiper and rearview mirror market. Thanks to protectionist Spanish legislation, the company faced no significant international competition. Regarding the key success factors of Lujan during these years, one of the senior managers interviewed stated, "in those years fluid commercial relationships were all that mattered. Quality was not a key issue, even price wasn’t. And we copied designs from 
major firms operating in Europe, especially the Germans." Lujan's corporate strategy up until 1986 can be characterized using the Corporate Strategy Triangle (Table 1).

\section{Table 2}

Lujan's Corporate Strategy Triangle before 1986

\begin{tabular}{|c|c|c|}
\hline $\begin{array}{c}\text { Cognitive Representation } \\
\text { DRIVING }\end{array}$ & $\begin{array}{c}\text { Corporate Strategic Initiatives } \\
\text { PACING }\end{array}$ & $\begin{array}{l}\text { Architectural design } \\
\text { FRAMING }\end{array}$ \\
\hline $\begin{array}{l}\text { Lujan at highest peak } \\
\text { Industry's market scope is national. } \\
\text { Key success factors in Spain: } \\
\text { Close commercial relationships. } \\
\text { No strong customer pressure on cost } \\
\text { or quality. } \\
\text { Low competitive intensity. }\end{array}$ & $\begin{array}{l}\text { Incremental local search } \\
\text { Geographic scope: Spain and } \\
\text { Portugal. } \\
\text { Market scope: all car manufacturers } \\
\text { operating in Spain. } \\
\text { Product scope: cables, windshield } \\
\text { wipers, sunvisors, mirrors. } \\
\text { Growth through market penetration } \\
\text { and product development. } \\
\text { Technological dependence on } \\
\text { partners }\end{array}$ & $\begin{array}{l}\text { High autonomy } \\
\text { Divisionalized. "Strategic control" } \\
\text { corporate style. } \\
\text { Operations and Marketing \& Sales } \\
\text { decentralized in small autonomous } \\
\text { business units. } \\
\text { Quantitative control measures appear } \\
\text { but budget culture lacking. } \\
\text { Corporate functions: finance, } \\
\text { administration, legal, commercial } \\
\text { advice to units (at their request). }\end{array}$ \\
\hline
\end{tabular}

Next, we will discuss Lujan's evolution during the 16-year period (1986-2002) covered by the study. This period can be divided in three stages, each characterized by a major strategic shift in the firm's corporate strategy that led to major changes in the scope of Lujan's business, its product mix, its key resources, and its basic technical capabilities, as well as in its organizational structure and processes.

\section{Becoming European (1986-1995)}

The first major shift in Lujan's corporate strategy began in 1986 and lasted for nearly a decade. This process of change will be discussed in terms of the three building blocks of corporate strategy described in the Corporate Strategy Triangle.

Corporate cognitive representation. On January 1, 1986, a significant event drastically and definitively changed the Spanish economy: Spain joined the EEC. This was the beginning of the end of Spain's isolation from Europe. Besides this regulatory breakthrough, which exposed Lujan to international competition, the auto components industry also had been undergoing important changes since the late seventies and early eighties.

Traditionally, European car manufacturers had developed their components in the countries where they manufactured their vehicles. In the late seventies, however, this practice began to change. Car manufacturers began to centralize component development in their regional headquarters. They also gradually stopped developing the components entirely themselves; 
instead, they started to share the development effort and costs with component manufacturers. This meant that the car makers' traditional policy of working with a large number of national suppliers, selected on a short-term basis, was replaced by a policy of dealing with a smaller number of more highly specialized suppliers, working under long-term agreements.

In light of this trend, Lujan's Chairman and then also CEO, Mr. Roig, understood that, from then on, the natural market space for leading European companies was no longer their home countries, but the whole of the EU. This was the case for several reasons: First, the centralization of the car manufacturers' component design and development decisions meant that component suppliers would have to have a presence close to the decision centers, which were located primarily in Germany, UK, France and Italy. Second, to position itself as a partner of car companies' long-term component development programs, a component supplier would need to have an image of technological strength - and because technology development required heavy investments, it could only be afforded by firms with a large market scope. Third, European deregulation was expected to facilitate pan-European business and remove trade barriers designed to protect national players.

These environmental changes wiped out Lujan's main advantages as a tier-one supplier to Spanish automobile plants: once component design and development decisions began to be made near the car companies' headquarters outside Spain, Lujan's strong local commercial relationships in Spain were no longer critical. What was more, its previous position as "King of Spain” ${ }^{\prime 4}$ in the components industry would be threatened by EU deregulation in 1993.

To hold on to its tier-one supplier status, Lujan would have to build a presence in the automotive industry's European decision centers, where as yet it was completely unrepresented, and combine competitive costs with an ability to become a technology developer. For Lujan, expanding into Europe from Spain entailed many challenges. First, it would require a huge financial effort, particularly for a privately held company with a turnover of only 37 million euros. Second, there would have to be a change in the organization's mindset, from being a technology follower to being its customers' technology partner. Third, the company would have to absorb the organizational and cultural impact of becoming a multinational and competing in countries with highly dynamic business environments. Finally, Lujan would have to rebuild all of its customer relationships virtually from scratch, as it had barely had commercial relations with the car makers' European headquarters in the past.

Mr Roig, Chairman of Lujan, explained how this positioning dilemma was presented:

“In June 1986, during a shareholders' meeting, I proposed three alternatives: First, concentrate on the Spanish market, with the prospect of continued high earnings and dividends for a while until the company eventually disappeared, within 7 to 10 years at most. Second, divest now by selling the company to one of the several international competitors that were offering to buy it. Third, engage in a process of European expansion, in line with the new logic of the car business, and become a truly European company."

\footnotetext{
${ }^{4}$ An expression used by one interviewee.
} 
Corporate strategic initiatives. The controlling shareholders decided to engage in a European expansion plan. Mr Roig commented that "we realized the need to battle for at least five or six years in Europe, before knowing whether this strategy would lead us to success or to a definitive failure. This uncertainty led some of our minority shareholders to sell their participations before we began our expansion in Europe." The new corporate vision was given expression in an international expansion plan aimed at positioning the company as a major European component manufacturer for all its product lines. For this purpose, the company had to get close to the big European manufacturers' decision centers. The tactic was to open Engineering Centers in each target country, led by native engineers hired "ad hoc," with the purpose of building the company's reputation as an innovative European manufacturer. The Chairman remembered that "we had to overcome the negative image that Spanish products tended to have in Europe in those days if we wanted to convince customers that we could become their technology partners." The purpose of the Engineering Centers was to establish strong relationships with the car manufacturers' R\&D centers. Only once this process was successful and contracts with the customer began to be agreed would Lujan consider beginning operations at the site. Thus, Lujan opened an Engineering Center in London in 1987 and a factory in Birmingham one year later.

In 1988 Lujan opened its second Engineering Center in Germany, to conduct dealings with the German manufacturers. That same year Lujan opened a third Engineering Center in France and bought 50\% of a local rearview mirror manufacturer, as French customers particularly appreciated suppliers with operations in the country.

After less than two years, Lujan was already present in three out of four key European areas (the exception was Italy) and had operations in two of them.

Architectural design. During these years, the company pursued strong organic growth, based on opening foreign subsidiaries and expanding operations in Spain in order to meet the increasing demand. Marketing and engineering structures were modified to create multi-country structures to market the company's products and provide engineering services in each country. No major standardization or restructuring efforts were promoted by the corporate center, and the strong commitment to divisional autonomy remained unchanged. Accordingly, each division developed its own systems and structure, based on its managers' views, and managed its own financial resources. The CEO reported that "divisions' practices were the projection of the idiosyncrasy of the divisional VPs. Beyond some broad indications coming from the corporate level, such as the need to expand in Europe and to increase quality and customer service, they behaved as if they were independent companies." Divisional autonomy was a feature on which Lujan prided itself. Its Chairman stated that autonomy was crucial, as "responsibility cannot exist without freedom."

The corporate style evolved with moderation. Control was based primarily on the monitoring of revenue figures. Budgets were prepared, but just as a general indication of targets, and were not subject to budgetary control. This situation changed in the early '90s, when the company gradually implemented a budgetary control system, though focused mostly on income statement accounts. Control still relied heavily on informal mechanisms, such as Mr. Roig's visits to the plants. Moreover, the cables and mirror divisions were led by Mr. Roig and Mr. Feliu's elder sons, reinforcing the controlling families' involvement in management. 


\section{Going Global (1995-2000)}

Corporate cognition. In 1995, Lujan's corporate management was still focused on the goal of consolidating the company as a major European technological partner of the car manufacturers. However, new developments taking place in the car and component industries gave rise to internal controversies about the soundness of the current framing of the competitive landscape.

Since the beginning of the '90s, competition among car manufacturers had been tough. The struggle among manufacturers to establish a global position led the industry to a situation of overcapacity, a particularly serious problem for an already mature, low-margin business. In the aftermath of excessive capacity building came a huge wave of industry consolidation that left the world market in the hands of a handful of firms. Manufacturers adopted revolutionary new initiatives aimed at achieving sharp cost reductions. As components accounted for between $60 \%$ and $70 \%$ of the cost of a new car, trimming the cost of supplies became the manufacturers' central concern. With that purpose, they began to operate under the concept of "global platforms." The idea was to cluster all of the different car models into "families" of similar models, build each family on a single common platform, and market the same models all over the world. This revolutionary concept increased the manufacturers' ability to share resources and components between models, consequently reducing costs. Gradually all the companies joined the trend to develop platforms and globalize their models. Additionally, car companies developed global sourcing policies and forced component manufacturers to produce complete systems instead of single components or sub-assemblies. This change permitted car manufacturers to lower costs by transferring several component development and assembly engineering costs to their suppliers and reducing the number of suppliers required for each model.

Technologically, electronics and information technology were becoming increasingly important and were expected to replace many mechanical and electrical functions of cars.

The car manufacturers' global sourcing policy and their willingness to rely on a smaller number of suppliers created competitive advantages for component manufacturers that were capable of supplying the manufacturers' assembly plants in any part of the world. This put pressure on component manufacturers to acquire a presence in all the high-volume or high-growth regions of the car business, triggering a process of industry consolidation and the formation of many alliances in the sector ${ }^{5}$. Tier 1 suppliers evolved towards the concept of "full-service suppliers." These firms were typically chosen three years in advance of the launch of a new model and were responsible for the design and development of prototypes of the systems they were contracted to supply. They were expected to guarantee the production of components until the manufacturer retired the model from the market.

Additionally, the components industry was affected by new legislation on safety (opening a window of opportunity for new products such as airbags or lumbar systems) and environmental issues, forcing companies to retire certain raw materials, such as PVC.

New trends in the market appeared to show that the globalization of the industry was the next challenge for tier 1 component manufacturers. One interviewee remarked, "however, there were

\footnotetext{
${ }^{5}$ Lujan's six main European competitors during the eighties no longer existed in the nineties, as all of them had been acquired by major American companies.
} 
many respected voices in the component industry claiming that keeping only a European business scope would still be a strong positioning for European firms."

Although its European expansion was not yet complete, Lujan's top management received several suggestions from its customers regarding the need for another change of direction. By the mid-90s, Lujan was signing contracts with European customers to supply plants located in Mexico producing for the European market. Lujan's Chairman and other members of the top management concluded that, if it was incapable of serving these kinds of overseas orders, in the long run not only would car manufacturers stop offering it such opportunities, but also its competitive position in Europe could be in jeopardy. Global competitors' size would give them a critical cost advantage, due to having operations in low labor cost locations, and economies of scale in R\&D and procurement. Also, manufacturers from the fast-growing East European market had started to solicit the company's services. Lujan's corporate management realized that global presence was the only way to hold on to its "tier 1" supplier status, which was a strong corporate objective, and so decided to embark on a new geographical expansion plan in order to follow their existing customers' global expansion and win new customers worldwide.

Corporate strategic initiatives. Lujan's repositioning was aimed at developing a presence in the two geographical areas that made up the "heart" of the car industry besides Europe - NAFTA and Japan - and in markets with strong growth potential such as Mercosur, India, Korea and China. Lujan's goal was to become one of the three global leaders in the lines of business in which it operated.

After assessing several alternatives for positioning within NAFTA, in 1995 Lujan opened a small sales office in Detroit, USA, and began its operations by renting a small plant in Monterrey, Mexico, the NAFTA country with the lowest production cost and highest market growth potential. Two years later, significant business growth persuaded the company to build its own plant and convert the Detroit sales office into an Engineering Center. Two years later, a second plant was opened in Monterrey and the Engineering Center was further expanded.

In India, Lujan entered into a joint venture with a local holding company in 1997, hoping to exploit the huge market potential that an emerging India offered. The joint venture was expected to supply components to a division of the Indian holding company and to international manufacturers operating in India.

In Japan, Lujan opened a Sales and Engineering Center in 1997. As access to the market was hampered by the "keiretsu" structure of the industry, Lujan formed alliances with four local companies manufacturing mirrors, cables, brake systems and plastics. Lujan marketed its Japanese partners' products outside Japan, while they marketed Lujan's products in Japan.

In 1999, Lujan entered the Asia-Pacific region by acquiring an equity stake in a components manufacturer in South Korea, with the aim of supplying the big car manufacturers.

In Mercosur, most of the best positioned car companies were already Lujan's customers and were expected to manufacture the global platforms for their latest small and medium-sized models in that area. Accordingly, in 1996, Lujan formed a joint venture in Brazil with a local firm and set up a plant for its three international lines of business. In 1998, the company became a fully owned subsidiary of Lujan and led the Brazilian market for rearview mirrors. In Argentina, Lujan acquired a controlling 55\% stake in a local component manufacturer in 1997. 
In 1999, Lujan expanded its European mirror business by acquiring a German manufacturer of mirrors for buses and industrial vehicles.

In early 2000, in a major new move, Lujan acquired the Mirrors Division of one of its major European competitors, the biggest acquisition in the company's history, representing an investment of roughly 60 million euros. This made Lujan the third largest producer of rearview mirrors in the world ${ }^{6}$ and gave it a manufacturing presence in Italy (the only important European location in which it had not yet established itself), France, Spain, Poland, Brazil, Argentina, India and Turkey.

Architectural design. The company retained its divisional structure, with highly empowered and independent divisions. However, international growth led top management to make major changes in the relationship between the corporate center and the business units by introducing a highly formal system of planning and control. There were also changes in corporate governance, with the inclusion of external directors on the Board.

The increase in the number and location of facilities made it impossible to carry on using the "taking a glance"-based control system, and standardization became the obvious solution". The company developed an integrated reporting system, designed to simplify corporate evaluation of the divisions. During 1995 and 1996, the corporate objective was to "become someone in the global market, and therefore, increasing revenues became the main divisional objective." $\mathrm{A}$ reform of the Board of Directors in 1998 made controls more rigorous and granular. In 1998, Lujan made its system of Planning and Control much more sophisticated. Budgetary control techniques were implemented that took into account not only financial results but also the growth of key balance sheet items and cash flows. Financial Management was restructured to give it an international profile, and long-term financing decisions were given a strategic status they had not had in the past. Divisions were framed as parts of a portfolio, according to their cash/growth profile. From that point on, the divisions lost control over their funds and could retain them only by "arguing their case" for investment in an internal competition for capital against the other units. "From then on, poor performers in cash generation got corporate support only if their mid-term strategy was very clear and performance expectations were satisfactory," said the CFO and Member of the Executive Committee.

The company's governance structure also evolved substantially. Traditionally, Lujan's Board met only once a year and was made up entirely of inside directors and members of the controlling families. The beginning of the global strategy in 1995 brought profound changes in the Board. Lujan became aware of its lack of expertise in international finance and hired two external directors who were specialists in this field. The Executive Vice-President reported that "we appointed the new CFO, with a strong background in corporate banking, and two of our financial advisors as Board Members, as we realized that we knew a lot about the car industry, but very little about international finance, a matter we couldn't neglect as a company willing to play in the global arena."

The entry of two private equity firms as partners, in 1997 and 1999, each with roughly 7\% of the capital, reinforced the presence of external directors and the financial bias of the Board.

\footnotetext{
${ }^{6}$ In fact, the acquisition put the company in first place in the world market, but two mergers between global competitors that took place shortly afterwards left Lujan in third place.

${ }^{7}$ In 2000, the Rearview Systems division alone had 14 plants in 8 countries.

8 Statement by Lujan's Executive VP.
} 
Additionally, an Executive Committee was created in 1998 to monitor the company's performance on a monthly basis.

\section{Getting Tighter (2000-2002)}

Corporate cognition. The already tight situation of the low-growth car industry got even tighter as a result of the global economic slowdown that began in 2000. Industry sales stalled and a contraction of 5\% was expected for 2002. In 2002, only China and Eastern Europe were expected to offer growth opportunities in the near future. In this context, car manufacturers redoubled their pressure on component manufacturers to cut costs, take on most of the responsibility for R\&D, and build larger amounts of complete component parts. Without exception, vehicle manufacturers were taking steps to reduce their total number of suppliers.

Already operating with low margins, component companies responded to these developments by increasing their production of modular systems, intensifying their global reach, doing their best to recoup heavy R\&D costs, investing in high-tech or unique components, and diversifying towards the aftermarket. The sector was expected to undergo a fresh round of consolidation, leading to an industry configuration characterized by concentration in a small number of powerful component giants. Tier 2 and tier 3 firms were expected to be the ones most exposed to the sales squeeze of the early 2000s and many of them were expected to disappear. In Europe in particular, a number of key automotive suppliers were showing signs of financial strain, triggering significant internal reorganization and, in certain cases, dramatic restructurings (Valsan, 2004).

In this context, Lujan began another major strategic shift. After a decade and a half of steady sales growth, and with its global expansion plan still unfinished, the company put margin strengthening at the top of the agenda, leaving the global expansion plan "on hold".

Corporate Strategic Initiatives. In a market tending towards concentration in a handful of big global players, this vision would demand slashing costs and developing new, exclusive, R\&Dbased, high-price products to escape from commoditization.

In 2000 the company acquired complete ownership of its rearview mirrors joint venture in France, in order to have better strategic control, and bought a small French company that produced window washers and that had a small subsidiary in Slovenia, a location that interested Lujan because of its low labor cost and the increasing presence of car manufacturers. The Polish and Turkish operations were further developed in order to move low-value-added production from Spain to these low-labor-cost countries. For the same purpose, the company started up a small operation in Romania.

Lujan took its first step in the booming Chinese market, with the aim of developing operations in Asia to supply its regional customers. In 2002, it signed a technical cooperation agreement with the second largest Chinese manufacturer of rearview mirrors. Lujan also acquired a fouryear call option on 70\% of the Chinese company's shares.

Aiming to develop future high-value growth opportunities, Lujan created two new lines of business. The first was the Aftermarket Division, whose purpose was to capture the potential of the retail business after its expected deregulation. The second was the development, through a strategic alliance, of an R\&D line in fractal antennas, designed to concentrate all of the vehicle's communications needs in a single small antenna. 
Architectural design. This third shift in Lujan's corporate strategy during the period under study had a much greater impact on its architectural design than the previous two, as the need for cost-cutting led the corporate office to prioritize synergy development, even if partly at the expense of the life-long philosophy in favor of a high degree of divisional autonomy. Diversity of systems, structures and procedures had multiplied with organic growth and, particularly, with acquisitions. Significant cost-cutting opportunities resulting from cross-business collaboration became apparent. A corporate director reported that divisions were "projections of the idiosyncrasy of the Divisional VPs. They were run as independent companies and, although today's corporate practices made their behavior more uniform, they still had very different business cultures." Accordingly, the corporate center launched a series of organizational changes with the objective of exploiting potential synergies, while at the same time preserving the "small company" culture that had contributed so much to Lujan's development. The CEO stated that the challenge was to achieve this objective "keeping our creativity, agility and competitiveness intact, preventing us from becoming an arrogant and bureaucratic conglomerate." The Chairman showed a similar concern regarding this issue.

A matrix structure was developed in all the international divisions. Business units, grouped either by product or by customer decision center, became responsible for business strategy, revenues, and return. Four global functional units were responsible for optimizing their areas of speciality: Operations, Technical (Engineering and R\&D), Purchasing, and Quality. Business unit and functional directors had worldwide responsibility. Each project, e.g. a long-term contract with a customer, was assigned to a Project Team. In 2000, Lujan began to implement individual, per-project income statements to increase the visibility of the return on all projects and so improve resource allocation and performance control.

A Human Resources Department was created at the corporate level to pursue corporate-wide initiatives, mainly to do with standardization of procedures, developing uniform salary scales across divisions, formal recruiting processes, career and development plans, policies for expatriates, and improved communications. Until then, Human Resources had been a responsibility of the divisions and had carried out only administrative functions.

Procurement was centralized as a corporate function in an effort to obtain scale economies and, more importantly, a policy of global sourcing was adopted. Lujan's Chairman noted that "we could not claim to be a global company and have $70 \%$ of our supplies coming from $50 \mathrm{~km}$ around our headquarters." For similar reasons, a new Logistics Department was created at the corporate level. The Logistics Director reported that "this allowed us to save many transportation costs, such as the cost of urgent air delivery, which had been usual in the past due to lack of effective coordination. It also helped to relieve the big plants in Spain from the task of managing the logistics of other plants worldwide, which had led to frequent disputes between plants.”

The R\&D function had also traditionally been performed by the divisions. The inter-unit Technology Committee proposed that the Cables Division's multi-country R\&D structure be used to help Rearview Mirrors decentralize the R\&D functions that required most customer contact, namely project management and development engineering, while the functions that did not demand close interaction with customers, accounting for $60 \%$ of total R\&D costs, were centralized in the industrial headquarters in Barcelona. R\&D was expected to be crucial, as 
major car components were expected to shift from a focus on electromechanics to a focus on electronics ${ }^{9}$ and IT.

\section{Discussion and Conclusions}

The purpose of this paper was to explore how corporate strategy can contribute to the success of a company exposed to a turbulent environment over a long period. While previous work based on case studies in multidivisional organizations put the stress on value creation based on architectural design initiatives, especially fostering self-organized designs, little emphasis has been devoted to understanding the contribution of the other two important roles depicted in the Corporate Strategy Triangle: cognition at the corporate level, and corporate strategic initiatives. The main features of Lujan's successful transit through the several, profound changes affecting its environment during the last sixteen years show that the Triangle framework is a good lens through which to examine the long-term dynamics of corporate strategy. Tables 2, 3 and 4 synthesize the main features of Lujan's corporate strategy triangle for each of the three stages identified in our study.

\section{Table 3}

Lujan's Corporate Strategy Triangle, 1986-1995

\begin{tabular}{|c|c|c|}
\hline $\begin{array}{c}\text { Cognitive Representation } \\
\text { DRIVING }\end{array}$ & $\begin{array}{c}\text { Corporate Strategic Initiatives } \\
\text { PACING }\end{array}$ & $\begin{array}{l}\text { Architectural design } \\
\text { FRAMING }\end{array}$ \\
\hline $\begin{array}{l}\text { Lujan's competitive position } \\
\text { eroded. } \\
\text { "peak in the fitness landscape loses } \\
\text { height" } \\
\text { Spain's accession to the EU slashes } \\
\text { legal barriers to entry. } \\
\text { Customers concentrate purchases in } \\
\text { European HQ. } \\
\text { Customer pressures for } \\
\text { cost/quality/service increase. } \\
\text { Need to become technology partner. } \\
\text { (image) } \\
\text { Need to develop European presence. }\end{array}$ & $\begin{array}{l}\text { Broadly: need to become a } \\
\text { European company and technology } \\
\text { partner of OEMs. "Off-line" long } \\
\text { jumps. } \\
\text { Entry into France, Germany, UK. } \\
\text { Market scope: car companies } \\
\text { headquartered in Europe. } \\
\text { Product scope: cables, mirrors, } \\
\text { windshield wipers, sunvisors, locking } \\
\text { systems. } \\
\text { Growth through market and product } \\
\text { development. } \\
\text { Technological learning from partners. }\end{array}$ & $\begin{array}{l}\text { High divisional autonomy. } \\
\text { Multi-country engineering and } \\
\text { marketing structures. } \\
\text { Divisional discretion for strategy, } \\
\text { structuring, systems, staffing and } \\
\text { resource allocation. } \\
\text { Control systems: } \\
\text { Budgetary control on income } \\
\text { statements. } \\
\text { Divisional leadership by family } \\
\text { members. }\end{array}$ \\
\hline
\end{tabular}

\footnotetext{
${ }^{9}$ The electronic content of a new vehicle was expected to rise to $40 \%$ in 2010 , compared to $22 \%$ in 2000 .
} 


\section{Table 4}

Lujan's Corporate Strategy Triangle, 1995-2000

\begin{tabular}{|c|c|c|}
\hline $\begin{array}{c}\text { Cognitive Representation } \\
\text { DRIVING }\end{array}$ & $\begin{array}{c}\text { Corporate Strategic Initiatives } \\
\text { PACING }\end{array}$ & $\begin{array}{c}\text { Architectural design } \\
\text { FRAMING }\end{array}$ \\
\hline $\begin{array}{l}\text { Lujan's European positioning } \\
\text { endangered by globalization of car } \\
\text { industry (peak loses height). } \\
\text { Car industry develops "global platforms" } \\
\text { and pressure for cost slash. Traditional } \\
\text { product margins slump. } \\
\text { Component R\&D weighted towards } \\
\text { suppliers. Focus on electronics. } \\
\text { Systems replace components. "Full- } \\
\text { service suppliers." } \\
\text { Need for scale in purchasing and R\&D } \\
\text { leads component industry toward global } \\
\text { positioning. } \\
\text { Consolidation in car and component } \\
\text { industries. } \\
\text { Regulation on safety and pollution. }\end{array}$ & $\begin{array}{l}\text { Global company and technology } \\
\text { partner. "Off-line" long jumps. } \\
\text { Geographic scope: entry into Mexico, } \\
\text { USA, Argentina, Brazil, Italy, Poland, } \\
\text { Turkey, Korea, Japan and India. } \\
\text { Market scope: car companies operating } \\
\text { in strategic or high-growth car industry } \\
\text { markets. } \\
\text { Product scope: systems tend to replace } \\
\text { components - gearshift systems, } \\
\text { rearview systems, lumbar systems, } \\
\text { brake systems, windshield wipers, } \\
\text { sunvisors, locking systems. } \\
\text { Growth: through product development } \\
\text { (worldwide) and market development } \\
\text { (outside Europe). } \\
\text { Proprietary R\&D in the three } \\
\text { international divisions. }\end{array}$ & $\begin{array}{l}\text { High divisional autonomy with higher } \\
\text { central coordination } \\
\text { Formalized planning and control } \\
\text { system. } \\
\text { Businesses seen as portfolio (BCG } \\
\text { matrix). Resource allocation is } \\
\text { centralized. "Strategic control style." } \\
\text { Private equity firms as minority } \\
\text { partners. } \\
\text { Entry of external directors on the Board }\end{array}$ \\
\hline
\end{tabular}

\section{Table 5}

Lujan's Corporate Strategy Triangle, 2000-2002

\begin{tabular}{|c|c|c|}
\hline $\begin{array}{c}\text { Cognitive Representation } \\
\text { DRIVING }\end{array}$ & $\begin{array}{c}\text { Corporate Strategic Initiatives } \\
\text { PACING }\end{array}$ & $\begin{array}{l}\text { Architectural design } \\
\text { FRAMING }\end{array}$ \\
\hline $\begin{array}{l}\text { Keep current representation, but } \\
\text { focus on static efficiency. } \\
\text { Global business. } \\
\text { Economic slowdown reinforces cost } \\
\text { pressures. } \\
\text { Systems R\&D increasingly in hands of } \\
\text { component manufacturers. } \\
\text { Consolidation aimed at getting global } \\
\text { scale in purchasing and R\&D. } \\
\text { Tier } 2 \text { and } 3 \text { firms in serious danger of } \\
\text { disappearance. } \\
\text { European component firms under } \\
\text { financial strain. }\end{array}$ & $\begin{array}{l}\text { Local search. Fcus on synergy and } \\
\text { differentiation } \\
\text { Geographic scope: unchanged. Call } \\
\text { option on a plant in China. } \\
\text { Market scope: unchanged. } \\
\text { Product scope: High R\&D bet toward } \\
\text { new, highly differentiated products } \\
\text { within current business lines. } \\
\text { Research in fractal antenna technology } \\
\text { (potential new line). } \\
\text { Growth: market development (retailers } \\
\text { or "aftermarket") and penetration in } \\
\text { NAFTA and Asia. } \\
\text { Reorganization of operations in low-cost } \\
\text { locations (Turkey, Poland, Romania). } \\
\text { Global sourcing }\end{array}$ & $\begin{array}{l}\text { Increased organizational } \\
\text { interdependencies } \\
\text { Creation of new corporate functions: } \\
\text { Purchasing, Logistics, HR. } \\
\text { Centralization of early stages of R\&D in } \\
\text { one location for the three international } \\
\text { divisions. } \\
\text { Adoption of a matrix organization } \\
\text { (business unit/function). } \\
\text { Inter-unit committees for knowledge } \\
\text { sharing in operations, technology, } \\
\text { quality and purchasing. } \\
\text { First CEO succession in company's } \\
\text { history. }\end{array}$ \\
\hline
\end{tabular}




\section{Corporate Cognition. DRIVING corporate strategy}

As seen in Tables 2 and 3, the company substantially shifted its "view of the world" three times during the sixteen-year period covered by the study. By 1986 it acknowledged the decreasing value of its competitive position in its effort to keep its "tier 1" manufacturer status. Repositioning itself to be near the European headquarters of car manufacturers became mandatory in the context of West European economic unification and the car makers' tendency to concentrate purchasing decisions and component development in their headquarters. Moreover, technological strength became a key success factor in light of the new business trends, characterized by long-term purchase agreements, including joint development projects between component manufacturers and car makers. In 1995, the globalization of the car industry and the increasing pressure on suppliers to reduce costs led Lujan's top managers to conclude that global presence and world-class R\&D would be crucial for Lujan's survival as a tier 1 component supplier.

In the last period, beginning in 2000, the third and final shift was characterized by a strong change in Lujan's agenda from a focus on developing an international market share "at any cost" to a new priority for consolidation of the organization and margin strengthening through R\&D and cost cutting, notably capturing synergies (Table 4). An external board member who promoted very strongly the need for this strategic shift commented, "it is extraordinarily difficult to make middle managers from the divisions understand this change in Lujan's priorities after a decade and a half of very aggressive commercial expansion. They just keep on bringing proposals to expand business and gain market share, and don't focus easily on the need to stop growing and focus on margins."

\section{Corporate strategic initiatives. PACING the corporate strategy}

During the first two of the three stages described in our story, the corporate level promoted strategic initiatives characterized by Gavetti and Levinthal (2000) as "long jumps" (Tables 2 and 3). Long jumps involve major alterations of the business model, aimed at achieving "dynamic efficiency" (Ghemawat and Ricart, 1993).

The long-jump pace promoted by Lujan was reflected in the company's positioning through the development of multiple small strategic bets, which were gradually augmented as promising results unfolded. This allowed the company to discard low-outcome moves costlessly, or at a low cost, constituting "off-line long jumps" (Gavetti and Levinthal, 2000). The company adopted this strategy in order to absorb complexity (Boisot and Child, 1999), engaging in multiple real options, particularly those that fit the definition of "corporate growth options" (Trigeorgis, 1996). Corporate growth options that set the path of future opportunities are of considerable strategic importance. Early investments can be seen as prerequisites or links in a chain of interrelated projects. The infrastructure and experience generated may serve as a springboard for developing future business opportunities.

During the period 1986-1995, the building of commercial relationships with car manufacturers across Europe that could benefit every business unit in the future and the opening of new plants for single product lines, with the possibility of extending the range of products in the future, are examples of Lujan's intuitive application of this idea. The gradual increases in the company's position in the United Kingdom, Germany and France, thanks to successful market penetration, show how the company "exercised" these successful growth options. These "offline long-jumps" enabled the company to deal with increasing environmental variety, which in 
the case of Lujan meant facing more new competitors and dealing with more varied and more sophisticated customers, as a result of internationalization and new product development. Moreover, fierce competition prompted the company to upgrade the competitiveness of internal processes that previously had not been considered critical, such as procurement, internal and external logistics, R\&D, and corporate finance.

A second long-jump based on "off-line" strategic moves began around 1995. The scope of the company's geographical market shifted yet again towards the development of a global position, with new operations and engineering centers in NAFTA, Mercosur, Korea and India and commercial agreements in Japan. During this period, the strategy of complexity absorption through multiple and varied initiatives was intensified, thanks to the development of new real options and several joint ventures. Entry into the US, Mexico, Brazil and Argentina was gradual and subject to unfolding events, i.e. market penetration, constituting new corporate growth options. Additionally, the multi-plants in Brazil and Mexico are examples of options to switch use (Trigeorgis, 1996). They provide a valuable built-in flexibility to switch from the current set of operations to new combinations in the future.

Lujan also engaged in several joint ventures. The alliances in Korea and India represented lowcost bets aimed at absorbing complexity through local partners with local market knowledge, while Lujan provided technological know-how and key international commercial relationships. In the past, Lujan had played this role in its alliances with international companies entering the Spanish market. This shift in its partnership roles reflects the extent of the company's qualitative evolution.

The acquisition, in early 2000, of the Mirrors Division of a major European competitor marks the transition between this period of long jumps and the subsequent stage focused on strategic initiatives characterized by an incremental local search aimed at achieving static efficiency. On the one hand, with this major acquisition the company developed new corporate growth options, thank to its entry into Poland, a beachhead for the fast-growing East European market, and Turkey, another fast-growing, low-cost area. At the same time, the acquisition allowed the company to obtain worldwide leadership status in the mirrors business, consolidating its position in Europe (Italy, France and Spain) and Mercosur (Brazil and Argentina). Rapid market share gains eased the development of economies of scale in purchasing and R\&D. Other acquisitions made after 2000 were specially focused on static efficiency, as illustrated by the purchase of the rearview mirrors joint venture in France, with the manifest purpose of securing better strategic control over operations; or likewise, the setting up of new operations in Romania and the reorganization of operations by moving production from the European Union to Poland and Turkey to take advantage of low-cost locations. Still, despite the new focus aimed at dealing with the environmental pressure to lower costs, the company still engaged in minor "off-line" long-jumps, such as the acquisition of the call option on a mirrors manufacturer in China and the establishment of an R\&D alliance to develop fractal antennas show.

It must be stressed that the corporate move towards a "local search" bias did not come after the company had completed its global expansion but in the middle of the process. Interviewees agreed that the company's global positioning could not be considered complete until Lujan had built up operations in the US and China, both unrealized objectives of Lujan's plan to become a global firm. However, the combination of a huge expansion effort and the global economic slowdown led the company to grind to a halt and focus on strengthening margins at the expense of fast growth. Also, Lujan's situation was common to most major European 
competitors by 2002 (Valsan, 2004) $^{10}$, suggesting that the company was not losing competitive momentum as a result of its need to refocus around static efficiency.

\section{Architectural design. FRAMING corporate strategy}

Our study of Lujan's initiatives regarding architectural design led us to develop a model of architectural design in turbulent environments.

Lujan's spectacular growth during the period 1986-1999 came at the expense of tolerating significant organizational inefficiencies, as the corporate focus was set on aggressively gaining market share "as the only possible path to secure survival," as one board member put it. By the late nineties, however, the company began to pay attention to its internal organization for two reasons: first, it needed to formalize its processes in order to prevent a "chaos trap" (Brown and Eisenhardt, 1998) that could arise if its traditionally highly organic managerial style was kept. The trend in companies towards increasing formalization as a result of growth has been extensively acknowledged in the management literature (Drucker; 1954, Mintzberg, 1983). Lujan's reported gradual sophistication and standardization of its corporate performance and control and information systems and the development of corporate human resources policies served this purpose, as did the switch to a matrix type of organization in the three international units. Second, by 2000 the global economic slowdown obliged the company to slow its "longjump" towards a global position, and concentrate on margin strengthening to compete in a stagnant market. That is why the company engaged in strong "static efficiency"-type initiatives, which were particularly evident in processes such as procurement, logistics and R\&D, and in the development of granular metrics for project control.

Through an analysis of the high-profile organizational initiatives that took place after 1999, we can identify several features of Lujan's corporate-level architectural design initiatives: the promotion of modular design, the development of standardized processes across divisions, the promotion of recombinations of resources and business opportunities, the development of channels for interdivisional collaboration, and the adoption of performance metrics consistent with corporate priorities. We consider these five characteristics, already identified and discussed in the literature, as the "building blocks" of a coherent management system, promoted by the corporate level.

Modular design. Modularity enhances innovation and adaptation at both the subsystem and system levels (Galunic and Eisenhardt, 2002). Limited constraints imposed by other subsystems boost the rate of innovation by autonomous units (Campbell, 1969, cited in Galunic and Eisenhardt, 2002), and architectural innovation generates opportunities for recombination across the entire system (Henderson and Clark, 1990).

Since its first steps in product diversification, early in its history, the company's top management had fostered modular design in the form of independent companies, at first for every product line, and since 1976, for product clusters grouped in highly autonomous divisions. Moreover, the divisions were divided into separate business units. Three interviewees remarked that, while the divisions broadly shared a common "Lujan culture," their evolution was divergent in structure, systems and style, as these characteristics were a consequence of

\footnotetext{
${ }^{10}$ This impression was shared by two interviewees.
} 
division leaders' own idiosyncrasy. Interdivisional unit communication and interdependence was very low until the late nineties. Recently, despite more formal control and centralized resource allocation, the divisions retained their autonomy in marketing, and operations.

Standardization. Despite its high growth, the company maintained its commitment to the car component industry, concentrating the units' broad product offerings among a small set of shared customers and under a common brand, two factors that foster standardization (Galunic and Eisenhardt, 2001). The organizational initiatives initiated up until 1999 also included important efforts to standardize procedures. Corporate purchasing and logistics departments developed company-wide standardized procedures. Planning and control and information systems were unified throughout the company, and divisional managers were appointed to the corporate committee, giving them the opportunity to find out about the situation of the divisions managed by their peers. Finally, human resources policies were unified for every unit under the company's strategic control.

Recombination. A partial solution to the dilemma of how to secure the advantages of exploration without losing the benefits of exploitation is to recombine elements of existing partial solutions (Levinthal and Warglien, 1999) by manipulating the interdependencies between different activities. A recombination strategy allows whole blocks of existing solutions to be changed, rather than modifying them piecemeal, thus exploiting knowledge without being trapped by it. In this way, the company acts following a "logic of opportunity" in the use of its resources (Eisenhardt and Bingham, 2003) and obtains inter-temporal economies of scope (Helfat and Eisenhardt, 2001) arising from the replacement of old businesses that used a particular resource by a new business that uses that resource in response to changing market conditions. Helfat and Eisenhardt (2001) suggest that inter-temporal economies of scope could also be obtained by reassigning particular functional areas to a new business, an approach that would require a matrix type of organization.

Lujan's recently created matrix organization has been conceived in a way that facilitates the recombination of changing business opportunities with manufacturing facilities worldwide for business units operating within each division. Operations managers have authority over plant activities worldwide and therefore are able to recombine operations' locations and business opportunities in such a way as to provide a competitive cost to business unit managers within each division.

Inter-unit collaboration. Recent ideas that have emerged under the "new managerial paradigm," such as Eisenhardt and Galunic's (2000) idea of coevolving and the work of Chakravarthy et al. (2001), suggest that the superior results of knowledge-sharing projects spreads from the interested units towards those promoted and led directly by the corporate center. Eisenhardt and Galunic (2000) state that the corporate offices that actually achieve synergies do not force collaboration but foster individual performance, letting businesses decide whether to work together as markets as the business evolves. Therefore, collaboration occurs only when two business unit managers believe that the links make sense for their respective businesses. The result is "a shifting web of relationships that exploits fresh opportunities for synergies and drops deteriorating ones” (Eisenhardt and Galunic, 2000).

The matrix organization created by Lujan in 2000 included interdivisional functional committees designed to help divisional functional managers find a channel to explore opportunities for developing synergies through knowledge-sharing (e.g., interchanging best practices) and activity-sharing. The divisional managers interviewed reported their satisfaction with these committees' performance, despite their relative novelty, and one of them stated that 
the spirit of the committees' objectives was not to increase bureaucracy but to "explore collaboration opportunities and, in particular, to prevent major mistakes due to lack of coordination." The recent creation of corporate procurement and logistics departments and the centralization of R\&D were initiatives resulting from the interdivisional Purchasing and Technology Committees' proposals, in response to the corporate mandate to find new ways to lower costs in these areas. This behavior corresponds to the idea of "framed self-organizing," through communication channels across groups, inspired by a small number of strict and simple rules (Brown and Eisenhardt, 1998). In Lujan's case, these "rules" consisted of a broad but strict mandate to improve the static efficiency of these processes. At the top management level, collaboration was also fostered by letting top divisional managers join the Executive Committee. Finally, at the employee level, inter-organizational communication was promoted through the issuance of a written version of the corporate Mission, Strategy, Objectives and Shared Values, and the development of a company-wide intranet to reinforce communication (e.g., advertising job opportunities in the company) and a corporate magazine.

Performance metrics led by corporate objectives. An organization's set of performance metrics and structure has a significant influence on actors' perceptions of their problem space. Performance metrics act as "attractors," influencing actors' attention to different facets of the company's environment. Only by offering a fresh perspective through a shift in performance metrics and through periodic changes of structure is further improvement possible. In this way, through architectural redesign, the cognitive representations of divisional management may be altered to make them fit with the new corporate priorities.

During the two periods of "long jumps," the company's metrics had fostered the achievement of ambitious sales targets, and had paid relatively little (though gradually increasing) attention to balance sheet items and strict cost control. During the last period, in contrast, corporate concentration on static efficiency was reflected in a new set of performance metrics aimed at biasing motivation toward cost awareness. Planning and Control tightened its grip by centralizing resource allocation between divisions and obliging them to justify very thoroughly their capital requirements, using financial tools such as discounted cash flows and financial ratios. Also, more granular metrics were developed, such as the implementation of a per-project income statement that enabled the company to fine-tune each individual project from tender to delivery. Finally, divisional directors' variable remuneration began to be linked to corporate performance in order to enhance inter-unit collaboration.

The abovementioned attributes identified at Lujan allow us to develop a model of architectural design for corporate advantage that we illustrate in Figure 3. 


\section{Figure 3}

Architectural Design in Turbulent Environments

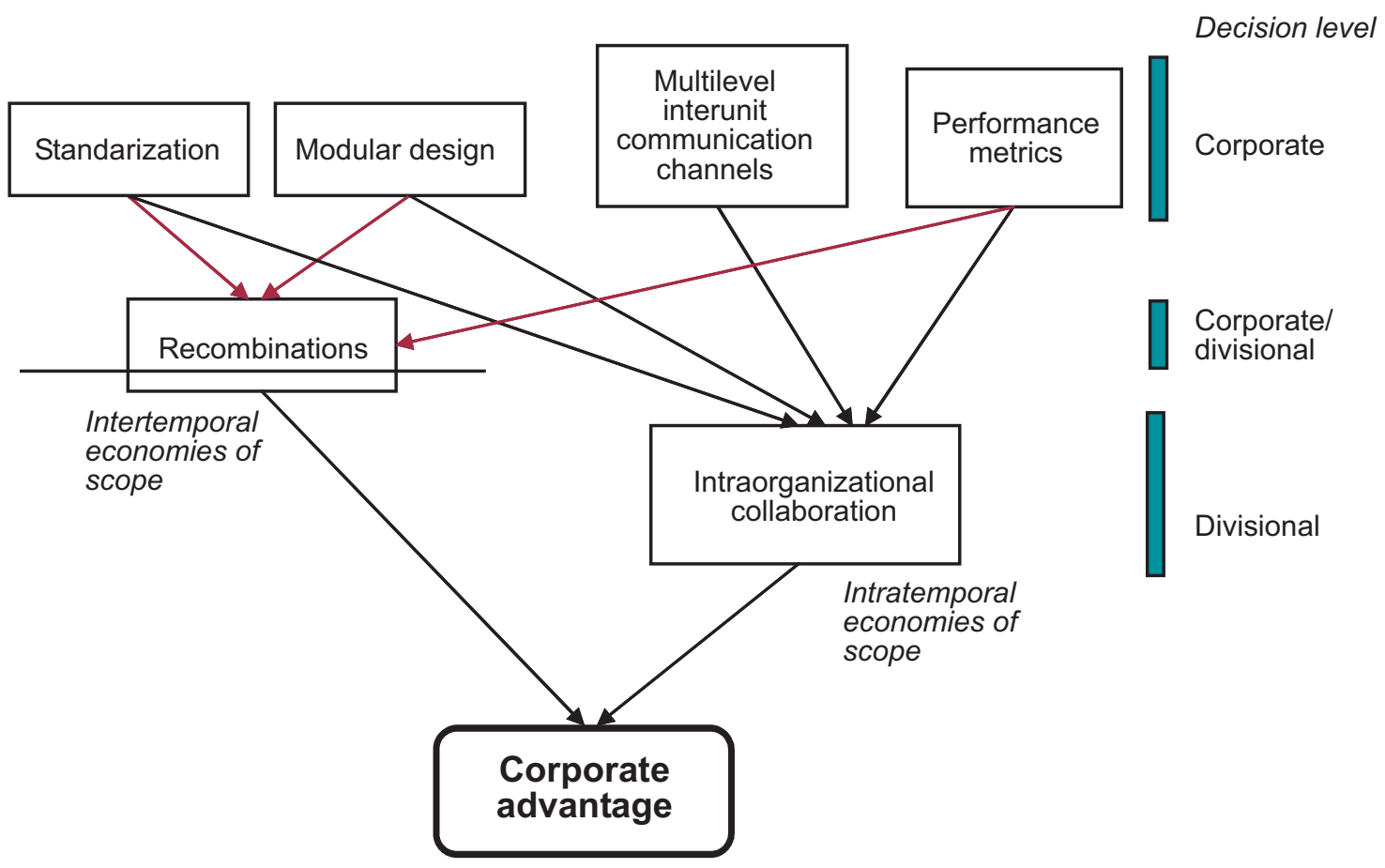

As Galunic and Eisenhardt (2001) remarked, standardization and modular design foster the development of recombination, whether by corporate initiative (when the decision involves several divisions) or by the division (if it affects only the division's own business units). Recombination permits the company to obtain inter-temporal economies of scope by "moving" a resource across subsequent business opportunities. Additionally, modular design and standardization, together with the existence of channels for inter-unit communication and systems of management evaluation based on both business and corporate issues, enable the emergence of opportunities for collaboration at the unit level. These collaboration initiatives allow intra-temporal economies of scope, characterized by the simultaneous utilization of a resource across different units, in the form of knowledge and/or activity sharing.

Both inter-temporal and intra-temporal economies of scope are sources of competitive advantage that the company obtains through architectural design. The important implication of our model, unlike previous work on the subject, is that corporate advantage is understood as the consequence of a company's behavior not only at the corporate level but also at the divisional and business unit level. The corporate level sets the architecture that facilitates recombination and allows collaboration opportunities to arise, but the actual recombination and opportunities are self-generated by the different business and functional units working together. This conclusion supports Bowman and Helfat's (2001) statement to the effect that corporate strategy is just a part of corporate impact on performance. As Lujan's case shows, the corporate level does not get involved in direct initiatives aimed at obtaining synergies, but plays an indirect role by developing organizational arrangements that help units to identify and implement collaboration initiatives. 
These arguments allow us to conclude that the impact of corporate strategy on a firm's performance is crucial. Through the Lujan story we can observe unmistakably how the company's three radical transitions, which notably impacted on Lujan's evolution from its position as "national champion" in Spain to its current status of global competitor, were led by corporate management. Our discussion also shows clearly that the Corporate Strategy Triangle provides a good lens to observe in more detail how the corporate level actually performs this role.

Our exploratory work suggests that there are three crucial challenges for corporate managers of firms facing radical environmental change. First, realize the need to modify their cognitive representation or "theory" of the business. Second, develop a set of corporate strategic initiatives that pace the firm, either toward "off-line" long-jumps, such as strategic alliances or real options, or toward local search processes, when environmental dynamism decreases temporarily as a result of economic slowdown. Finally, architectural design reconciles the need for coordination with the need for rapid response through organizational arrangements that foster and ease self-organized collaboration at the interdivisional level. These structural designs acknowledge that firms are complex, adaptive systems and, consequently, must be managed according to the properties of such systems.

This work also helps to illustrate the inadequacy of an often repeated statement about corporate strategy, derived from mainstream research: that corporate strategy exists only in diversified firms. This sometimes implicit assumption led to studies that sought to identify the sources of corporate performance by isolating company, industry and corporate effects. Lujan would qualify as a car component manufacturer, i.e. a single business company. However, as this account shows, Lujan actually has a corporate decision level that has had a crucial impact on its long-term survival and performance.

Further research could aim at systematizing the analysis of the Corporate Strategy Triangle with the help of agent-based models. In this way, the relationships between cognition, strategic initiatives and architectural design could be described and understood more thoroughly. For instance, issues such as the performance impact of different corporate styles and different degrees of strategic discipline in environments of varying turbulence could be observed. 


\section{References}

Anderson, P. 1999. Complexity Theory and Organization Science. Organization Science 10: 216-232.

Bar-Yam, Y. 1997. Dynamics of Complex Systems. Perseus Publishing.

Boisot, M., Child, J. 1999. Organizations as adaptive systems in complex environments: the case of China. Organization Science 10: 237-252.

Bowman, E. 1995. Next steps for corporate strategy. In Advances in Strategic Management, Vol. 12B: 39-64. JAI Press, Inc., 1995.

Bowman, E., Helfat, C. 2001. Does corporate strategy matter? Strategic Management Journal 22: 1-23.

Brown, S., Eisenhardt, K. 1998. Competing on the edge: strategy as structured chaos. Boston MA: Harvard Business School Press.

Brush, T., Bromiley, P. 1997. What does a small corporate effect mean? A variance components simulation of corporate and business effects. Strategic Management Journal 18: 825-835.

Caldart, A., Ricart, J. E. 2004. Corporate Strategy Revisited: A View from Complexity Theory. European Management Review 1: 96-104.

Chang, S., Singh, H. 2000. Corporate and industry effects on business unit competitive position. Strategic Management Journal 21: 739-752.

Cyert, R., March, J. 1963. A Behavioral Theory of the Firm. Malden, MA: Blackwell Business.

Drucker, P. 1954. The Practice of Management. Harper Collins.

Eisenhardt, K., Brown, S. 1999. Patching. Restitching business portfolios in dynamic markets. Harvard Business Review 77(3): 72-82.

Eisenhardt, K., Sull, D. 2001. Strategy as simple rules. Harvard Business Review 78(1): 107-116.

Fiol, C., Huff, A. 1992. Maps for managers: Where are we? Where do we go from here? Journal of Management Studies 29: 267-285.

Galunic, C., Eisenhardt, K. 2001. Architectural innovation and modular corporate forms. Academy of Management Journal 44: 1229-1250.

Gavetti, G., Levinthal, D. 2000. Looking forward and looking backward: cognitive and experiential search. Administrative Science Quarterly 45: 113-137.

Ghemawat, P., Ricart i Costa, J. 1993. The organizational tension between static and dynamic efficiency. Strategic Management Journal 14: 59-73.

Goold, M., Campbell, A. 1987. Strategies and styles. Oxford: Blackwell.

Goold, M., Campbell, A. 1998. Desperately Seeking Synergy. Harvard Business Review 77(5): 131-143.

Goold, M., Campbell, A. 2002. Designing effective organizations: How to create structured networks. Jossey Bass. 
Grant, R. 2003. Strategic planning in turbulent environments: evidence from the oil majors. Strategic Management Journal 24(6): 449-462.

Hawawini, G., Subramanian, V., Verdin, P. 2003. Is Performance Driven by Industry- or Firmspecific Factors? A New Look at the Evidence. Strategic Management Journal 24 (1): 1-16.

Henderson, M., Clark, K. 1990. Architectural innovation: the reconfiguration of existing product technologies and the failure of the established firm. Administrative Science Quarterly 35: 9-30.

Hill, C., Hoskisson, R. 1987. Strategy and structure in the multiproduct firm. Academy of Management Review 12(2): 331-341.

Kauffman, S. 1993. The Origins of Order. New York: Oxford University Press.

Lawrence, P., Lorsch, J. 1967. Organization and Environment. Boston MA: Division of Research, Harvard Business School.

Levinthal, D. 1997. Adaptation in rugged fitness landscapes. Management Science 43: 934-950.

Levinthal, D., Warglien, M. 1999. Landscape design: Designing for local action in complex worlds. Organization Science 10: 342-357.

Levitt, B., March, J. 1988. Organizational Learning. Annual Review of Sociology 14: 319-340.

March, J. 1991. Exploration and exploitation in organizational learning. Organization Science 2: 71-87.

March, J., Simon, H. 1958. Organizations. New York: John Wiley.

Marion, R. 1999. The edge of organization: chaos and complexity theories of formal social systems. Thousand Oaks, California: Sage Publications.

Markides, C., Williamson, P. 1996. Corporate diversification and organizational structure: A resource-based view. Academy of Management Journal 39: 340-367.

McGahan, A., Porter, M. 1997. How much does industry matter, really? Strategic Management Journal 18: 15-30.

McKelvey, B. 1997. Quasi-natural organization science. Organization Science 8: 352-380.

McKelvey, B. 1999. Avoiding complexity catastrophe in coevolutionary pockets: Strategies for rugged landscapes. Organization Science 10: 294-321.

Miller, D. 1990. The Icarus paradox: How excellent organizations can bring about their own downfall. New York: Harper Business.

Mintzberg, H. 1983. Diseño de organizaciones eficientes. Buenos Aires: El Ateneo.

Mintzberg, H., Ahlstrand, B., Lampel, J. 1998. Strategy safari: A guided tour through the wilds of strategic management. London: Prentice Hall.

Nelson, R., Winter, S. 1982. An Evolutionary Theory of Economic Change. Cambridge, MA: Bellknap Press. 
Pascale, R. 1999. Surfing the edge of chaos. Sloan Management Review 40(3): 83-95.

Peters, T., Waterman, R. 1982. In search of excellence. Lessons from America's best-run companies. New York: Harper \& Row.

Porter, M. 1980. Competitive strategy. Techniques for analyzing industries and competitors. New York: The Free Press.

Prahalad, C., Bettis, R. 1986. The Dominant Logic: A New Linkage between Diversity and Performance. Strategic Management Journal 7: 485-501.

Prahalad, C., Hamel, G. 1990. The core competences of the corporation. Harvard Business Review 68(3): 79-91.

Rivkin, J. 2000. Imitation of Complex Strategies. Management Science 46(6): 824-844.

Rumelt, R. 1991. How much does industry matter? Strategic Management Journal 12: 167-185.

Schmalensee, R. 1985. Econometric diagnosis of competitive localization. International Journal of Industrial Organization 3: 57-70.

Siggelkow, N., Levinthal, D. 2003. Temporarily Divide to Conquer: Centralized, Decentralized, and Reintegrated Organizational Approaches to Exploration and Adaptation. Organization Science 14(6): 650-669.

Simon, H. 1996. The Sciences of the Artificial. Cambridge, MA: MIT Press.

Stacey, R. 1993. Strategic management and organisational dynamics. London: Pitman Publishing.

Stacey, R., Griffin, D., Shaw, P. 2000. Complexity and management. Fad or radical challenge to systems thinking? Routledge, London and New York.

Trigeorgis, L. 1996. Real options: Managerial flexibility and strategy in resource allocation. Boston: MIT Press.

Valsan, Anil 2004. Commercial Vehicle Components in Europe: A Metamorphosis in Progress? The Auto Channel, May 2004.

Walsh, J. 1995. Managerial and organizational cognition: Notes from a trip down memory lane. Organization Science 6: 280-321.

Yin, R. 1989. Case Study Research: Design and Methods. Beverly Hills, CA: Sage. 